of anatomy of that name. The first Alexander Monro, when appointed to the chair in 1720, kept a list of his students which is now shown, as also is a printed copy of the first thesis to be presented for the degree of M.D., Edinburgh. It is entitled "De Dolore", by John Monteith, and the date is 1726. Later works on view are the second edition (1800) of Edward Jenner's "Inquiry into the causes and effects of variolae vaccinae", the first British edition of Beaumont's "Experiments and Observations on the gastric juice, etc." (1838), Morton's "Remarks on the mode of administering ether" (1847), and J. Y. Simpson's "Account of a new anaesthetic agent" (chloroform) (1847). Another landmark of medical literature is Lister's "Introductory Lecture", delivered in 1869 when he succeeded James Syme in the chair of clinical surgery at Edinburgh, and with it may be seen a manuscript set of notes of Lister's lectures, in the writing of one of his most distinguished students and successors, Prof. Caird. A feature of the exhibition, and the most spectacular item, is a fine collection of illustrated herbals, including a magnificent copy of "De Historia Stirpium", by Leonard Fuchs, dated 1542, with coloured wood-cuts, and a catalogue of the Physic Garden of Edinburgh (1683), by the first professor of botany, James Sutherland. The exhibition, which has been arranged through the kindness of Dr. L. W. Sharp and the Library Committee of the University, will remain open until June 3 .

\section{Rhinology and Folk-Lore}

IN a recent paper ( $J$. Laryng. and Otol., 57, 272 ; 1943) on this subject, Dr. J. D. Rolleston remarks that in contrast with the dearth of popular synonyms for the ear and larynx, the nose enjoys an abundance of such terms, which he suggests is mainly due to the prominent position which the nose occupies in the face. Another explanation of these numerous synonyms is the connexion of a large red nose with chronic alcoholism, though such a connexion has been greatly exaggerated. One of the earliest beliefs connected with the nose is that it is the portal of entry of the life or the soul, as is seen from the wellknown passage in Genesis relating to Adam. On the other hand, according to Sir James Frazer, the nose has been regarded by several savage races as the path by which life leaves the body. A popular belief in a close relationship between the size of the nose and the sexual organs in both sexes dates back to ancient times, and seemed at first to be confirmed at the end of the last century by the work of Fliess and others, who under the title of 'reflex neurosis' recorded a number of cases of uterine disease which had been cured by treatment of abnormal conditions of the nose. It now appears that the supposed connexion between the two organs in both sexes has been greatly exaggerated.

The folk-lore connected with sneezing is extremely abundant and dates back to remote ages, as is exemplified by many passages in the Bible, Homer, the Greek anthology, Xenophon and Petronius Arbiter. In accordance with the general rule in medical folklore, preventive measures are remarkably scanty in the case of rhinology and are chiefly employed in the management of epistaxis ; whereas therapeutic measures are extremely numerous and can be classified under the headings of remedies of human origin, animal remedies, plant remedies, mineral cures, hydrotherapy, charms, patron saints and miscellaneous cures.

\section{William Bartram of Philadelphia : Naturalist and Traveller}

THE son of John Bartram, botanist to His Majesty for the Floridas, William Bartram (1739-1823) shared his father's interest in Nature, and in 1773-74 carried out an extensive survey in Georgia and Florida. The results of his "Travels" he communicated in two manuscript volumes to his patron, Dr. John Fothergill, an Edinburgh medical graduate who had settled, and made a fortune, in London. After the death of Fothergill, the manuscripts came into the possession of Sir Joseph Banks, and they are now in the library of the British Museum (Natural History). Through the generosity of the American Philosophical Society and the John Bartram Association, this interesting record, thoroughly annotated by Francis Harper, has just been published (Trans. Amer. Phil. Soc., N.S., 33, 121 ; Nov. 1943). It gives a picture of the primeval wilderness of the south-east of North America, of the beauties of scenery and the wonders of plants and animals, of the Creek, Cherokee and Seminole Indians, until then largely unspoilt by the 'civilization' of white men. It is true that many of the wonders described by Bartram were regarded with scepticism in later years by those whose authority gave them some claim to pronounce judgment ; but it is one of the gratifying features of the investigations of Mr. Harper, who followed the Bartram trails over some ten thousand miles, that the authorities have been confounded and Bartram's accuracy vindicated, even in the much-disputed matters of the painted vulture of Florida and the bellowings of the alligators of St. John's, Florida, so circumstantially figured in the traveller's drawing, reproduced as Plate xiv in this paper.

\section{Railway Signalling on London Transport}

According to a paper read recently in London by R. Dell before the Institution of Electrical Engineers, the power-signalling installation on the railways of the London Passenger Transport Board now covers 160 miles of double track. There are 3,281 stop signals, 2,726 of which are fitted with trainstops. Track circuits number 4,347 and there are 1,326 pairs of points. Although automatic signals are used wherever possible, 112 signal cabins are in use at junctions or connexions in the track layout. The passenger-train car-miles run each year total approximately $159,150,000$. Power signalling has been in use practically throughout the system since it was electrified. The electrification of the District Line and the installation of power signalling commenced in 1904 and was completed by the end of 1905. The London Electric Tube Lines were equipped with power signalling from the start-the Bakerloo and the Piccadilly Lines in 1906 and the Hampstead Line in 1907. The Central London Railway was converted to power signalling in 1913 and the City and South London Railway in 1919. Except for these last two installations, the whole of the signalling system was originally operated on D.c. and track circuits were of the D.c. type with polarized relays in order to avoid improper operation by stray current from the traction system.

In the original installation the signals were all electro-pneumatically operated, with a moving spectacle in front of a fixed light for the tunnels and with semaphore arms in the open. All signals for passenger movements were provided with automatic trainstops. Although they gave remarkably satis- 